\title{
停留殬丸に関する研究
}

\author{
第 1 報 Luteinizing hormone-releasing hormone (LH-RH) 負荷時における
}

停留睾丸患者の plasma LH, FSH 及びtestosterone值の変化について

東北大学医学部泌尿器科学教室 松 田 尚 太 郎*
(主任:突户仙太郎教授)

\section{A STUDY ON CRYPTORCHIDISM}

Report 1. Changes in Plasma Levels of FSH, LH and Testosterone in Cryptorchidism with Loading of Luteinizing Hormone-Releasing Hormone

\section{Shotaro Matsuda}

Department of Urology, Tohoku University School of Medicine, Sendai

(Director: Prof. S. Shishito)

In an attempt to throw light on the problem of cryptorchidism, the author conducted a controlled experiment on three adult groups consisting of normal subjects and patients with unilateral or bilateral cryptorchidism. Their plasma levels of FSH, LH and testosterone were measured and compared among groups before and after LH-RH loading. As a result, it has been found that both groups of cryptorchidism had comparatively high levels at baseline for both FSH and LH in plasma, especially in the bilateral group, and positively responded to LH-RH loading, indicating their hypothalamo-hypophyseal systems probably functioning normally.

The plasma levels of testosterone at base line were highest in the unilateral cryptorchidism, next in the normal, and lowest in the bilateral cryptorchidism group. But their reaction with loaded LHRH was generally poor in both groups of cryptorchidism, suggesting that, in cryptorchid cases, unilateral and bilateral alike, the capacity of the testicle to secrete testosterone was generally depressed, freeing central suppression. That probably accounts for the high values of plasma FSH and LH observed in such patients.

The quantitative reciprocal correlation observed between plasma FSH and testosterone indicated the negative feedback regulation clearly active for FSH and testosterone. Presumably FSH is playing some role in the secretion of testosterone.

\section{緒言}

停留金丸は1786年に John Hunter ${ }^{1)}$ によりはじめて記 載されたといわれて括り，以来数多くの報告がなされて きた。 その発生頻度をみると, Alanら ${ }^{2)}$ にれば 4 歳 以下の男子の $6.7 \%$ に また 4 歳以上 15 歳までの男子に 9.8\%も認められたと報告してお於りまたGilbert ${ }^{3)}$ は泌 尿器科外来患者の $0.23 \%$, 岡元ら ${ }^{4)}$ は $1.02 \%$ に認めたと 報告している. 当教室では外来患者総数の $1.3 \%, 15$ 歳以 下の小児患者中 $13.4 \%$ も認めている ${ }^{5)}$ 。このよう飞高頻

\footnotetext{
*研究生
}

度にみら゙れる停留蓻丸の成因については諸説があるが， 正常な宰丸の下降の mechanism すら解明されていない 現状ではその真の成因はいまだ不明である，また停留側 の粹丸に和ける造精機能障害の問題のみでなく, 片側停

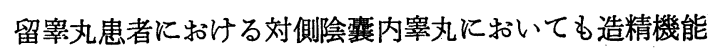
障害がしばしばみられ , 何故そのような変化がくるの か全く不明である. 一方停留莘丸患者のホルモン環境に 関する報告は決して少なくないがそのほとんどはgonadotropin に関するものかあるいは停留粹丸内での steroid hormone の合成過程の障害に関するもので間脳一下垂体 
一性腺系の一貫したホルモン環境に関する報告はほとん どみられていない。このように停留輁丸については未解 決の問題が山積しているが，今回著者は停留蛙丸患者の 間脳一下垂体一性腺系を明らかにする為にそれら患者に luteinizing hormone-releasing hormone (LH-RH) を負 荷し，LH，FSH， testosterone を同時に測定して若干の 知見を得たのでここに報告する。

\section{検查対象並びに検査方法}

検查対象として今回は特にホルモン学的にみて未熟な 小児例を除く青, 壮年の患者のみを検查対象とした。 即ち東北大学医学部泌尿器科を訪れた $17 \sim 52$ 歳の 片側 停留暲丸患者 8 名, 両側停留殬丸患者 5 名を検査対象と した。またコントロールとして正常男子 5 例をえらびこ れら症例の plasma luteinizing hormone (LH), plasma follicle stimulating hormone (FSH) 拈よび plasma testosterone を測定するとともにこれら症例に対して LHRH 負荷試験を施行した.

検查方法は早朝空腹時採血してそれを前値とし, 合成 LH-RH 0.1mgを筋注した後コントロール群は 10 分， 20 分，30分，60分，90分にそれぞれ採血し，停留䔂丸患者 群に対しては注射後30分，60分，90分，120 分にそれぞ
れ採血して plasma LH, FSH 及び plasma testosterone を測定した. plasma LH, FSH の測定法については著者 らが既に報告しているので詳細は省略するが，二抗 体法による radioimmunoassay 法で測定した．尚測定值 は $\mathrm{mIU} / \mathrm{ml}$ (2nd-IRP-HMG) で表示した. 一方 plasma testosterone は Hasan ら ${ }^{8)}$ の変法にしたがつて radioimmunoassay 法により測定したが詳細は既に 報告してあ る9)のでここでは省略するが測定值はng/dlで表示した。

\section{測定成績 (Table 1,2. Fig. 1)}

1) 正常人の plasma LH, FSH, testosterone 及び LH-RH 負荷試験

a) plasma LH: 正常人 5 例の base line 值は $2 \sim 20$ $\mathrm{mIU} / \mathrm{ml}$ で平均 $10 \pm 7 \mathrm{mIU} / \mathrm{ml}$ であつた。また LH-RH を負荷すると，個々の症例でみれば peak は20分で 2 例， 30 分で 1 例， 60 分で 2 例であつたが，平均值でみ ると Fig. 1 如く30分で peak を示し，その值は58 \pm 24 $\mathrm{mIU} / \mathrm{ml}$ であつた。 またその平均増加率(p(peak value)/ $\mathrm{b}$ (baseline value)) は5.8倍であつた。

b) plasma FSH : base line 值は $2 \sim 20 \mathrm{mIU} / \mathrm{ml}$ で平均 $7 \pm 4 \mathrm{mIU} / \mathrm{ml}$ であつた。 また LH-RH を負荷すると, 個々の症例の peak は, 10分で 1 例認められたがその他

Table 1 Plasma LH and FSH

\begin{tabular}{|c|c|c|c|c|c|c|c|c|c|c|c|c|}
\hline & \multicolumn{5}{|c|}{$\mathrm{LH}(\mathrm{mIU} / \mathrm{ml})$} & \multirow{3}{*}{$\mathrm{p} / \mathrm{b}$} & \multicolumn{5}{|c|}{$\mathrm{FSH}(\mathrm{mIU} / \mathrm{ml})$} & \multirow{3}{*}{$\mathrm{p} / \mathrm{b}$} \\
\hline & \multirow{2}{*}{ 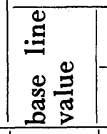 } & \multicolumn{4}{|c|}{$\begin{array}{l}\text { minutes after administration } \\
\text { of LH-RH }\end{array}$} & & \multirow{2}{*}{ 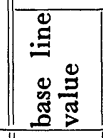 } & \multicolumn{4}{|c|}{\begin{tabular}{|c|} 
minutes after administration \\
of LH-RH
\end{tabular}} & \\
\hline & & 30 & 60 & 90 & 120 & & & 30 & 60 & 90 & 120 & \\
\hline$\underset{(5 \text { cases })}{\text { normal mean }} \pm$ s.d. & $10 \pm 7$ & $58 \pm 24$ & $52 \pm 20$ & $38 \pm 16$ & - & 5.8 & $7 \pm 4$ & $15 \pm 11$ & $17 \pm 9$ & $12 \pm 8$ & - & 2.4 \\
\hline $\begin{array}{l}\text { unilateral } \\
\text { cryptorchidism } \\
\text { mean } \pm \text { s.d.( } 3 \text { cases })\end{array}$ & $19 \pm 6$ & $163 \pm 47$ & $145 \pm 68$ & $124 \pm 61$ & $106 \pm 43$ & 7.6 & $20 \pm 9$ & $47 \pm 13$ & $39 \pm 12$ & $35 \pm 13$ & $55 \pm 46$ & 2.7 \\
\hline $\begin{array}{l}\text { bilateral } \\
\text { cryptorchidism } \\
\text { mean } \pm \text { s.d.( } 5 \text { cases })\end{array}$ & $38 \pm 29$ & $147 \pm 83$ & $139 \pm 52$ & $130 \pm 98$ & $90 \pm 53$ & 3.9 & $\mid 44 \pm 39$ & $78 \pm 62$ & $83 \pm 66$ & $88 \pm 58$ & $100 \pm 55$ & 2.3 \\
\hline
\end{tabular}

s.d.: standard deviation, $\mathrm{p}$ : peak value, $\mathrm{b}$ : base line value

Table 2 Plasma testosterone (ng/di)

\begin{tabular}{|c|c|c|c|c|c|c|}
\hline & \multirow{2}{*}{$\begin{array}{l}\text { base line } \\
\text { value }\end{array}$} & \multicolumn{4}{|c|}{ minutes after administration of LH-RH } & \multirow{2}{*}{$\mathrm{p} / \mathrm{b}$} \\
\hline & & 30 & 60 & 90 & 120 & \\
\hline normal mean \pm s.d. ( 5 cases) & $544 \pm 122$ & $930 \pm 134$ & $956 \pm 103$ & $786 \pm 227$ & - & 1.7 \\
\hline $\begin{array}{l}\text { unilateral cryptorchidism } \\
\text { mean } \pm \text { s.d. ( } 8 \text { cases) }\end{array}$ & $802 \pm 186$ & $721 \pm 175$ & $866 \pm 274$ & $760 \pm 207$ & $835 \pm 222$ & 1.1 \\
\hline $\begin{array}{l}\text { bilateral cryptorchidism } \\
\text { mean } \pm \text { s.d. ( } 5 \text { cases) }\end{array}$ & $459 \pm 193$ & $572 \pm 294$ & $614 \pm 253$ & $534 \pm 237$ & $560 \pm 251$ & 1.3 \\
\hline
\end{tabular}

s.d.: standard deviation, $\mathrm{p}$ : peak value, $\mathrm{b}$ : base line value 
Fig. 1 Response of plasma LH, FSH and testosterone to LH-RH administration in normal males and cryptorchidism.

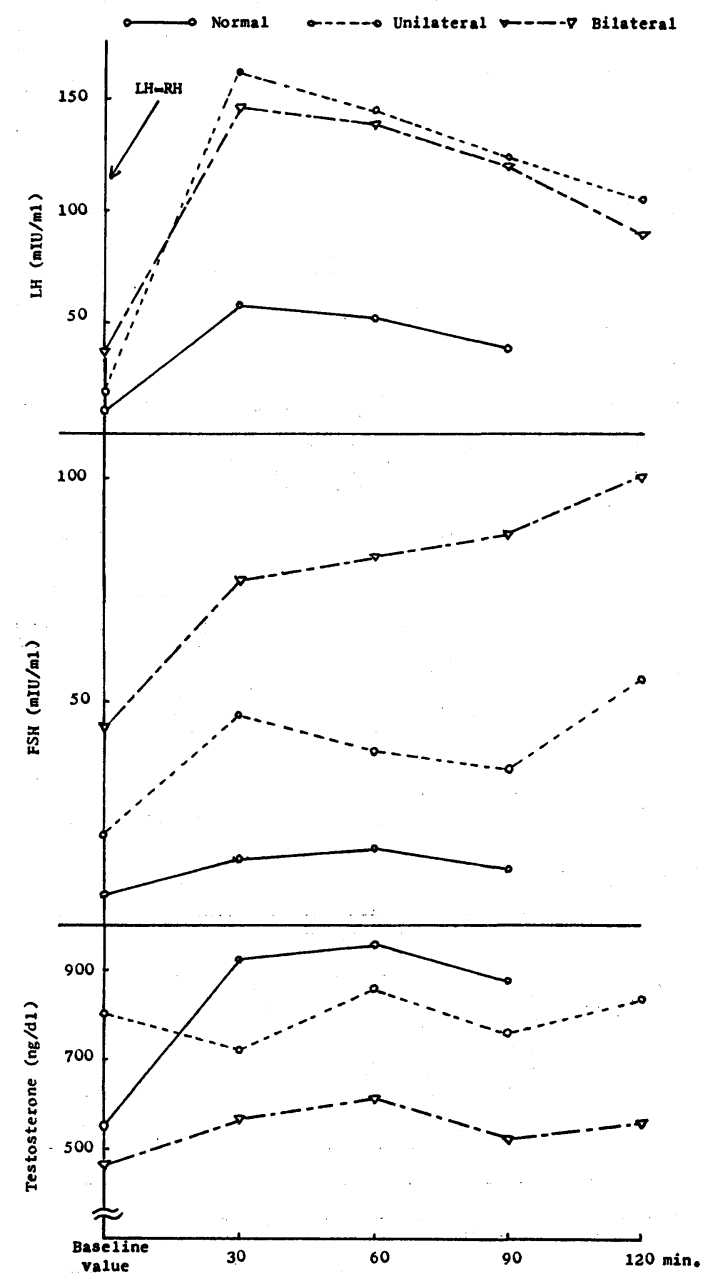

の者は30〜60分に peak に達した。平均値でみればFig. 1 の如く60分でpeakに達し，その值は $17 \pm 9 \mathrm{mIU} / \mathrm{ml}$ で あり, またその平均増加率は2.4倍であつた。

c) plasma testosterone : base line 值は 430 1180ng/dl で平均544士122ng/dlであつたまな LH-RH を負荷する といずれの症例にも増加がみられ, peak は個々の症例 をみれば LH-RH 注射後10分で peak に達しだ者が 1 例 みられたが他の者はすべて60分で peak に達し, 平均值 でもやはり60分で peak に達し，その值は956士103ng/dl であつた。 またその平均増加率は1.7 倍であつた。

2）片側停留宰丸患者の plasma LH, FSH, testoste- rone 及び LH-RH 負荷試験

a) plasma LH : 片側停留䔂丸患者 8 例の base line 值 は13〜 $53 \mathrm{mIU} / \mathrm{ml}$ で平均 $19 \pm 6 \mathrm{mIU} / \mathrm{ml}$ であつた。また LH-RH を負荷すると peak は 8 例中 7 例が30分で peak に達し，1例のみが60分でピークに達した. また平均値 でみてもやはり30分で peak に達し，その值は163土47 $\mathrm{mIU} / \mathrm{ml}$ であつた。 またその平均増加率は 7.6倍であつ た。

b) plasma FSH : base line 值は $6 \sim 39 \mathrm{mIU} / \mathrm{ml}$ で平 均 $20 \pm 9 \mathrm{mIU} / \mathrm{ml}$ であつた。 また LH-RH を負荷すると 8 例中 6 例が30分で peak に達し，2 例が120分で peak に達したが, 平均值でみると 120 分で peak に達し，そ の值は $55 \pm 46 \mathrm{mIU} / \mathrm{ml}$ であつた。また平均増加率は 2.7 倍であつた。

c) plasma testosterone : base line 值は400〜 1160ng/dlで平均802士186ng/dlであつた．また LH-RH 負荷試験 では 8 例中 2 例が LH-RH に全く反応せずに負荷前値が 最も高值を示し, 30分でpeakを示した者が 1 例, 60分で 3 例，120分で 2 例と一定した傾向はみられなかつた。 しかし平均值でみると60分でpeakに達し，その值は 866 $\pm 274 \mathrm{ng} / \mathrm{dl}$ であつた．またその平均増加率は1.1倍であつ た。

3）両側停留产丸患者の plasma LH, FSH, testosterone 及び LH-RH 負荷試験

a) plasma LH : 両側停留宰丸患者 5 例の base line 值 は $1 \sim 70 \mathrm{mIU} / \mathrm{ml}$ で平均 $38 \pm 29 \mathrm{mIU} / \mathrm{ml}$ であつた.また LH-RH を負荷すると30分で peak に達した者が 5 例中 2 例, 60 分で 2 例, 90 分で 1 例であり, 平均值でみると 30分で peak に達し, その值は $147 \pm 83 \mathrm{mIU} / \mathrm{ml}$ であつ た。またその平均増加率は3.9 倍であつた。

b) plasma FSH : base line 值は $3 \sim 139 \mathrm{mIU} / \mathrm{ml}$ で平 均 $44 \pm 39 \mathrm{mIU} / \mathrm{ml}$ であつたまな LH-RH を負荷すると 30分でpeakに達した者 1 例，60分で 1 例，90分で 1 例， 120 分で 2 例と一定していなかつたがやや反応遅延の傾 向がみられた。 また平均值でみても peak は 120分にあ り, その值は $100 \pm 55 \mathrm{mIU} / \mathrm{ml}$ であつた. そしてその平 均増加率は 2.3 倍であつた。

c) plasma testosterone : base line 值は98〜 720ng/dlで 平均459土193ng/dlであつた。 また LH-RH を負荷すると 5 例すべてが LH-RH に反応を示したが，その peak は 30 分で 2 例, 60 分で 2 例， 120分で 1 例と一定していな かつたが平均值でみると60分で peak に達し，その值は

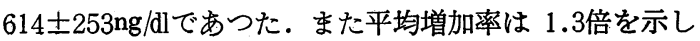


ていた。

\section{総括並びに考按}

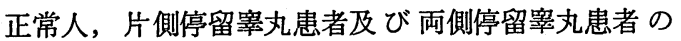
LH-RH 負荷時に拈ける plasma LH, FSH 及び testosterone 值を比較してみると, まず plasma LH の base line 值は両側群が最も高く, 次に片側群が高く, 正常群が 最も低值を呈した。一方 LH-RH 負荷に対しては三群と もよく反応していずれの群も30分でpeakに達したが，そ のpeak值は片側群が最も高く, 次に両側群が高く, 正常 群が最も低値を呈した。次に plasma FSH に扣いては, まず base line 值は両側群が最も高く, 次に片側群が高 く，正常群が最も低值であつた。 また LH-RH 負荷に対 しては三群ともよく反応したが, peakは正常群が60分に あり, 片側群, 両側群はともに 120分にあつて停留粹丸 患者群はいずれもかなり反応遅延の傾向を呈した。また そのpeak值は両側群が最も高く, 次に片側群が高く, 正 常群が最も低值であつた. 以上の如く正常群に比して停 留殬丸患者群の方が plasma gonadotropin $の$ base line 值 が高く, LH-RH にもよく反応することより, 停留辡丸 患者の間脳一下垂体系には特に異常はないのではないか と思われた. 次に plasma testosterone をみるとまず base line 值は片側群が最も高く, 次に正常群で, 両側群が最 も低值を呈した。このように片側群が正常群よりも高值 を呈したのは片側停留輁丸患者 8 例中 2 例が異常に高值 を呈していたためであり，なぜそれらが異常高値を呈し たかは不明である. 次にこれら三群に対する LH-RH 負 荷についてみると, まず peak は三群とも60分にあつた が, その peak 值は正常群が最も高く, 次に片側群が高 く, 両側群が最も低值を呈したままた平均増加率でみる と正常群が最も高く, 次に両側群が高く, 片側群が最も 低值を呈した。このように両側群, 片側群とすにLH-RH に対する反応が非常に悪かつたといらことは, 両側停留 拳丸患者はもちろんのことではあるが片側停留輧丸患者 に拈いても性腺に打ける testosterone 産生能が落ちてい ることが考えられた.このように testosterone の分必が 低下しているため中枢抑制が充分ではなく，その結果 先に述べたようにこれら停留涬丸患者では plasma LH, FSH が高値を示しているものと思われた。また Shirai $ら^{6)}$ は片側停留宰丸患者の反対側陰囊内辠丸にも造精機 能低下を認めたと報告しているが，単にそのような造精

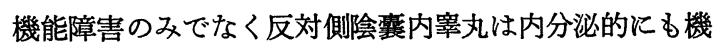
能低下を呈していることが考えられた．このように反対 側陰囊内殬丸が造精機能のみでなく内分泌能も低下をき
たしているのはほぼ確かであり大変興味ある事実である が，何故このように対側睾丸にまで変化がくるのか今 回のホルモン測定では明らかにすることはできなかつた が, 著者は今後この点に関して更に追求してゆく予定で ある。

次にFSHと testosteroneの関係は現在な和不明な点が多 く定説はないが, Altwein ら ${ }^{10)}$ はラットで実験的に停留 䡤丸をつくり plasma LH, FSH を測定した結果，FSH は直ちに上昇するが LH はあまり上昇しないことを確 め停留莘丸に怙いては FSH feed-back regulation が活 発であると報告しており，またSizonenko ら ${ }^{11)}$ は停留粹 丸患者に対して HCG test を行つた結果, testosterone 分 泌は主にLHによりコントロールされているが, exogenous HCG に対する䔂丸の反応は endogenous FSH に依 存していたことよりFSHは testosterone 分泌に間接的に 重要な役割を果しているのであろらと述べている.その 点について著者の結果をみてみると（Fig. 1)，片側群 と両側群のFSHと testosterone の間には quantitativeな 反比例的関係が明瞭に存在しているが，それは Altwein $ら^{10)}$ の述べているごとく negative feed-back regulation が活発な為であると考えられ, やはり testosterone 分泌 にはFSHが何らかの役割を果しているのではないかと考 えられた，しかしいまだ症例数も少いので今後更に症例 を重ねてこれらの点を追求し発展させてゆく予定であ る.

\section{結 語}

正常人と片側及 び 両側停留窧丸患者の plasma LH, FSH抽よび testosterone 值を測定し, 更に LH-RH 負荷 試験を施行したが, 停留辠丸患者, 特に両側停留睪丸患者 群において plasma LH, FSH が高值を呈し, また LHRH 負荷にもよく反応したことより片側並びに両側停留 殬丸患者の間脳一下垂体系には異常がないと考えられ た。

一方 plasma testosterone は片側群で正常群より高値を 呈したが両側群は正常群より低値を呈し，また LH-RH 負荷に対しては片側群, 両側群ともに反応が悪いという 結果を得た．以上のことより両側停留童丸患者のみでな く，片側停留殬丸患者においても鼻丸における testosterone 産生能が括ちていることが考学られ, その為に中 枢抑制がとれて plasma LH，FSH が高值を呈したもの と考えられた。

またFSH值は testosterone 值と反比例的相関性を呈し たことよりFSHの testosterone に対する negative feed 
back regulation は明瞭かつ活発であり, testosterone 分 泌にはFSHも何らかの役割を果しているのではないかと 考觉られた。

（稿を終るに臨み御䅰篤なる御指導と御校閲を睗つた 恩師穴戸仙太郎教授に心より感謝の意を表すると共に, 直接種ふなる御指導を賜つた当教室白井将文講師並びに ホルモン測定に御協力いたたいた本学放射線医学教室中 村護講師, 本学薬剤部米沢健三先生に深謝します。

尚，本論文の要旨は第19回日本不妊学会総会に於て発 表した。）

\section{文 献}

1) Hunter, J.: Lewis, L.G.: J. Urol., 60, 345, 1948. より引用.

2) Alan, B. \& McCutcheon, M.B., B.S.: Med. J. Australia, 2, 353, 1922.

3) Gilbert, J.B.: J. Urol., 46, 740, 1941.
4) 岡元健一郎, 牧角 格: 西日泌尿, 31,71 , 1869.

5) 白井将文, 佐々木桂一: 臨泌, 26, 877, 1972.

6) Shirai, M., Matsushita, M., Kagayama, M., Ichijo, S. \& Takeuchi, M.: Tohoku J. exp. Med., 90, 363, 1966.

7) 米沢健三, 中村 護, 白井将文, 松田尚太郎 : 泌尿紀要, 19，611，1973.

8) Hasan, S.H., Von Berswordt-Wallrabe, R. \& Neumann, F.: Hormone metab. Res., suppl. No. 3, 113, 1971.

9) 白井将文, 松田尚太郎, 中村 護, 米沢健三 : 臨泌, 28, 269, 1974.

10) Altwein, J.E. \& Gittes, R.F.: Invest. Urol., 10, 171, 1972.

11) Sizonenko, P.C., Cuendet, A. \& Paunier, L.: J. Clin. Endocrinol. Metab., 37, 68, 1973.

（1975年 2 月 22 日受付） 